робототехнике в школе будет являться важным этапом развития технических умений учащихся.

Список литературы:

1. Ершов М.Г. Роль образовательной робототехники в формировании инженерного мышления школьников. - URL: http://confer.cschool.perm.ru/tezis/Ershov.doc

2. Ушаков А.А. Робототехника в средней школе - практика и перспективы. URL: www.uni-altai.ru/info/journal/vesnik/3365-nomer-1-2010.html

\title{
Исследование особенностей выявления одаренности у детей дошкольного возраста
}

Калаиникова Е.А., педагог-психолог, ДОУ «Солнышко», п. Чульман E-mail: 721-00-00@mail.ru

Одна из насущных задач современного образования - выявление, поддержка и развитие творческой, креативной личности. Соответственно, научная обоснованность, технологическая проработанность формирования творческой, креативной личности в настоящем приобретают актуальность и значимость.

О том, что проблема выявления одаренности у дошкольника действительно существует, доказывают исследования ученых. На международной научнопрактической конференции «Современные тенденции развития дошкольного образования в мире» был представлен доклад доктора психологических наук, профессора Психологического института РАО Богоявленской Дианы Борисовны по теме «Проблемы выявления одаренности в дошкольном возрасте».

В реальной практике дошкольных учреждений, остро ощущается необходимость постановки целенаправленной, планомерной и систематической работы педагогического коллектива по выявлению, поддержанию и развитию одаренных дошкольников. В эту работу должны быть включены родители, психологи и педагоги.

Совершенствуя условия для выявления и поддержки одаренных детей, Постановлением Правительства Российской Федерации от 17 ноября 2015 г. № 1239 утверждены правила выявления детей, проявивших выдающиеся способности, сопровождения и мониторинга их дальнейшего развития.

Интеллектуальность - по коэффициенту интеллекта выявляют одаренных детей, и это один из немногих бесспорных до недавнего времени признаков одаренности.

Базовым психическим процессом, обеспечивающим развитие интеллекта в младшем дошкольном возрасте, выступает восприятие и наглядно-действенное мышление. Следовательно, при диагностике интеллектуального развития нами подбирались такие методики и задания, которые учитывали возможности восприятия и наглядно-действенного мышления для организации предметной, игровой, продуктивной деятельности испытуемых. Базовым психическим процессом в старшем дошкольном возрасте является память. В основе многих методик диагностики интеллектуального развития старших дошкольников лежит тест на выявление общей осведомленности испытуемых в разных областях знаний и окружающем мире.

В методике А.Р. Лурия детей можно попросить подобрать картинки или символы, которые помогут им лучше запомнить называемые взрослым слова, и объяснить свой 
выбор. «Ребенок дошкольного возраста мыслит, вспоминая» - Л.С. Выготский. Согласно исследованиям А.Р. Лурия, ребенок 5-7 лет может запомнить от 5 до 7 слов. На практике некоторые дети данного возраста по методике, показывают более высокие результаты.

1. Методика двойной стимуляции (МДС) предназначена для изучения уровня функционирования памяти через оценку глубины обработки информации при запоминании. Способные дети, из 15 воспроизведенных слов взрослым, запоминают 1214, а иногда и все 15. Именно такой вариант диагностики памяти позволяет не просто измерить количество запоминаемого материала, как утверждают авторы Н.Н. Мельникова, Д.М. Полев, О.Б. Елагина, но и оценить используемые ребенком способы запоминания, их потенциальную продуктивность. В основу разделения интеллектуальных субтестов на блоки ПСИ и КСИ в методике ГОШ положено одно из традиционных представлений о структуре интеллекта (Р. Кеттелл). Согласно этому общий интеллект является результатом взаимодействия двух факторов: текучий или флюидный интеллект - природная составляющая и кристаллизованный - который определяется совокупностью знаний и навыков и является мерой овладения культурой того общества, к которому человек принадлежит. На основе стандартных баллов, полученных по отдельным субтестам строился интеллектуальный профиль, позволяющий наглядно убедиться в слабых и сильных сторонах интеллекта.

По форме Б, как правило, наши дети набирают достаточное количество баллов, чтобы обучаться на уровне «не ниже среднего», а некоторые способные и более того.

Из 14 испытуемых 5 детей показали высокие результаты по всем субтестам, но убедительно одаренными их нельзя назвать, так как мы рассматривали их интеллект. А три главные составляющие человеческой одаренности: интеллект, творчество, самоанализ.

Развивая интеллект ребенка, не стоит забывать о творческих способностях, а занимаясь совершенствованием творческих, недопустимо забывать о формировании интеллекта, ведь сочетание творческих способностей с высоким уровнем интеллекта и создает активную, эмоционально уравновешенную, независимую в суждениях личность.

2. Креативность проявляется в дошкольном возрасте в условиях специально организованной среды (предметно - информационная обогащенность, образцы креативного поведения).

По результатам диагностик характеристики 14 детей соотнесли по уровням: 1 дети с высоким уровнем интеллекта и креативности; 2 - дети с высоким уровнем интеллекта и низким уровнем креативности; 3 - дети с низким уровнем интеллекта и высоким уровнем креативности; 4 - дети с низким уровнем интеллекта и креативности.

Первую группу № 1 - составили 5 детей: Егор К., Варвара 3., Миша Е., Антон Н., Сережа М. Дети уверены в своих способностях, имеют адекватный уровень самооценки, обладают внутренней свободой и высоким самоконтролем. Проявляя интерес ко всему новому и необычному, они очень инициативны, но при этом успешно приспосабливаются к требованиям современной действительности, сохраняя независимость суждений и действий. Без сомнений это дети способные, но констатировать, что они одаренные мы не можем, так как показатели интеллектуальных способностей и качеств в некоторых случаях невысоки.

3. Рассматривая скоростные, эргические и вариативные показатели, данные соотнесли в следующие индивидуально-типологические группы (по Т.И. Чирковой) 


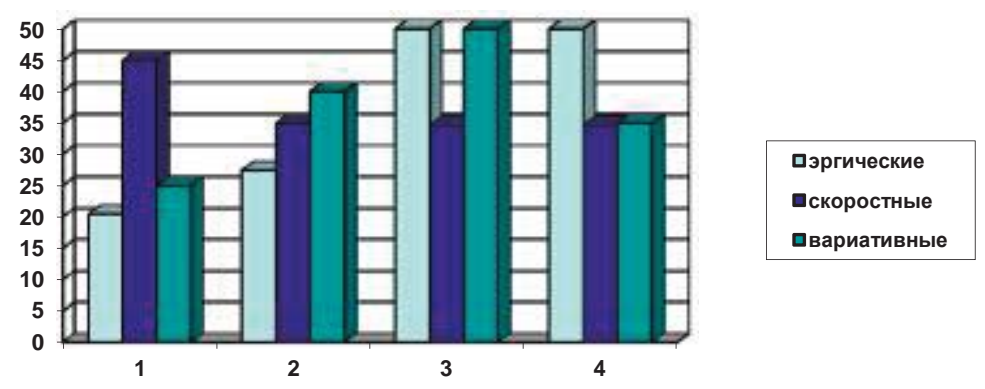

Рис. 1. Индивидуально-типологические группы

1 группа. Интеллектуальную активность эти дети реализуют за счет скорости интеллектуальной деятельности, хотя эргические показатели ее незначительны, а вариативность - среднего уровня.

2 группа. В интеллектуальной деятельности у детей наблюдается четко выраженная склонность реализовать свою активность за счет внутренних побуждений. Скоростные показатели неустойчивы.

3 группа. Интеллектуальную активность дети реализуют преимущественно за счет выраженного стремления к новизне и разнообразию используемых способов решения задач. Эргические показатели высокие. Дети охотно принимаются за новые задания, но нуждаются в постоянной дополнительной внешней стимуляции и контроле взрослых.

4 группа. Интеллектуальную активность дети данной группы реализуют преимущественно за счет эргических показателей. Отмечается устойчивость в скоростных и вариативных показателях среднего уровня.

Не малую важность в выявлении одаренности имеет диагностика общих и интеллектуальных способностей. В работе использовали обобщающую таблицу, разработанную Н.Ю. Посталюк. У выделенной группы детей характеризовали способности и интеллектуальные качества: гибкость и самостоятельность мышления, готовность памяти, способность к обобщению, способность к доведению до конца, способность к оценочным действиям.

Попытаемся создать модель одаренного ребенка, учитывая индивидуальнотипологические характеристики наших детей, составляющих первую группу по уровню интеллекта и творческих способностей: если взять высокий уровень скоростных показателей Миши Е. добавить высокий уровень эргических показателей Антона Н. или Егора К. добавить высокий уровень вариативных показателей Сережи М. или Варвары 3. только тогда вырисовывается некая модель одаренного ребенка.
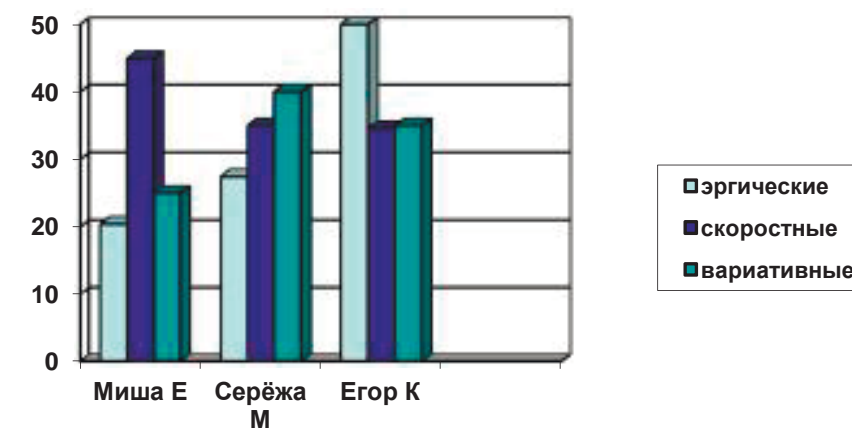

Рис. 2. Примерная (авторская) модель одаренного ребенка 
Понятие творчества как способности к развитию деятельности по собственной инициативе базируется на такой структуре личности, в основе которой лежит доминирование познавательной мотивации. Говоря о структуре личности, подчеркивается, что «функциональный орган» творческих способностей человека не может быть сенсорным - им является личность в целом.

Важно, чтобы жизнь ребенка, его личность, его одаренность не оказались только средствами, обслуживающими те или иные потребности взрослых.

\section{Список литературы:}

1. Лейтес Н.С. Ранние проявления одаренности // Вопросы психологии. 1988. №4. C.11-15.

2. Матюшкин А.М. Загадки одаренности. М., 1997.

3. Доровской А.И. 100 советов по развитию одаренности. М., 1997.

4.Кулемзина А.В. Детская одаренность: психолого-педагогическое исследование. Томск, 1999.

5. Варламава Е.П., Степанов С.Ю. Психология творческой уникальности. - М.: Изд-во Институт психологии РАН, 2002. - 256с.

6. Гальперин П.Я. К психологии творческого мышления/ П.Я. Гальперин // Вопросы психологии. - 1982. - №5.

7. Дружинин В.Н. Когнитивные способности: структура. Диагностика, развитие. - М.:ПЕР СЭ; СПб.: ИМАТОН-М, 2001. - 224 с.

8. Дружинин, В.Н. Психология общих способностей.3-е изд. - СПб.: Питер, 2008. $-368$

9. Мельникова Н.Н., Полев Д.М., Елагина О.Б. Готовность к школьному обучению Методика ГОШа. - Челябинск: ПсиХРОН, 2007.

10. Выготский Л.С., Лурия А.Р. Культурное развитие специальных функций: память/Этюды по истории поведения. - М., 1993.

\section{Учителями славится Вилюйск...}

Каратаева А.А., студентка, Вилюйский педагогический колледжс имени Н.Г. Чернышевского, г. Вилюйск E-mail: vpc_proekt@mail.ru

Научный руководитель: к.n.н. Борисова 3.H.

Анализ количества опубликованных вакансий за 2015 год на портале www.jobsmarket.ru показал, что в десятку самых востребованных специальностей профессия учителя не вошла. К этому можно добавить, что Президент Всероссийского фонда образования Сергей Комков сообщает, что нехватка учителей в регионах составляет около $40 \%$.

Ни для кого не секрет, что престиж современного педагога упал так низко, что вызывает острую тревогу не только для тех, кто профессионально занимается воспитанием и обучением детей. 